\title{
Alvorlig sinnslidende i fengsel - noe må gjøres
}

\author{
Til enhver tid finnes det mange alvorlig sinnslidende innsatt i norske fengsler. Dette er et problem som er lite \\ kjent i store deler av helsevesenet og blant allmennheten. Det må opprettes ressursavdelinger for innsatte \\ med psykiske lidelser og store atferdsavvik.
}

\begin{abstract}
I flere hundre år har fengselsvesen og helsevern hatt overlappende oppgaver og funksjoner for personer med mentale sykdommer og avvikstilstander. En studie om forholdene i Europa og USA på 1930-tallet ga opphav til Penroses lov (etter forfatterens navn): I et land vil det alltid være et omvendt proporsjonalt forhold mellom dimensjoneringen av fengselsvesen og av psykisk helsevern (1). En norsk studie tyder på at loven fortsatt er aktuell også i Norge (2).
\end{abstract}

En stor internasjonal metaanalyse fra 2002 med 62 studier med flere enn 23000 innsatte viste at blant innsatte menn, som utgjør over $90 \%$ av fengselsinnsatte, var andelen med psykotisk sykdom, alvorlig depresjon og personlighetsforstyrrelser klart høyere enn i normalbefolkningen. Hos kvinner var psykotisk lidelse og depresjon litt vanligere, mens personlighetsforstyrrelser var klart sjeldnere (3). Norske landsdekkende undersøkelser har vist liknende prevalensverdier (4). Forekomsten av personlighetsforstyrrelser for tiden er under kartlegging.

Norge har få fengslede personer i forhold til sin befolkning sammenliknet med resten av den vestlige verden og relativt sett bare en tidel av hva som er tilfellet i USA. Dersom forekomsten av psykotisk sykdom blant innsatte i USA var den samme som i Norge, ville dette innebære at USA har ti ganger så mange psykotiske i fengsel i forhold til befolkningen som det Norge har. Dette forklarer at fengslene etter nedbygging av psykiatriske sykehus i USA er blitt kalt Amerikas nye mentalsykehus (5).

\section{Norske lover}

Norge har klare regler, både i straffeprosessloven $\S 459$ og indirekte i straffeloven $\S 44$, som i utgangspunktet skal gjøre det utelukket at alvorlig sinnslidende, dvs. dem med tjeneste. Noen foretrekker fengselsopphold fremfor sykehusopphold.

Dette avdramatiserer et stykke på vei den i utgangspunktet altfor høye forekomsten av psykose blant innsatte i norske fengsler. Det som er bekymringsfullt er de med psykose som ikke er behandlingsmotiverte og som ikke kan gis antipsykotisk medikasjon mot sin vilje. Dette er det ikke anledning til å gjøre. Også i fengslene må det beskyttes mot mulig misbruk av behandling av psykotisk klientell som er uønsket i psykiatriske døgninstitusjoner. Å fremstille ikke-behandlingsmotiverte innsatte for injeksjonsbehandling på en psykiatrisk poliklinikk reiser vesentlige praktiske og etiske problemer.

Prinsipielt er det to hovedelementer i interessemotsetningene mellom fengselsvesen og psykiatriske døgnavdelinger. Det ene gjelder personer med sterkt atferdsavvikende personlighetsforstyrrelse (eventuelt psykopatiske), innsatte uten psykotisk tilstand. Disse oppfattes med rette som unormale og plagsomme. Fengselsansatte mener de bør overføres til psykiatrien. Dette er det meget liten adgang til, både i forhold til lovverket og fordi behandlingsmulighetene innen psykiatrien er meget små (6). Det andre elementet gjelder ikkebehandlingsmotiverte innsatte med klare psykotiske trekk og som i fengselet ikke făr den behandling de etter loven har krav på. Disse pasientene blir ofte kasteballer mellom fengsel og psykiatri.

Dette har skapt mye misnøye både i fengselsvesenet og i helsevesenet. Jeg har erfaring fra begge sider i denne striden. Det er lett å forstå begge: Psykisk helsevern har sterkt begrenset døgnkapasitet med lukkede avdelinger og må alltid overholde øyeblikkelig hjelp-plikten. Derfor sendes pasienter lett tilbake til fengsel, som på sin side ikke

\section{«En prioritering av innsatte med psykotiske tilstander vil kunne gi langt mer forsvarlige forhold»}

manifest psykose, skal sitte i fengsel. Hvordan er det da mulig at mange personer med psykotisk sykdom er innsatt i norske fengsler? Noen av disse personene venter på innleggelse. Noen er godt stabilisert gjennom antipsykotisk behandling, tar sin medikasjon frivillig og med forståelse, lider ikke under fengslingen og har en god og omsorgsfull oppfølging fra fengselets betjenter og helse- ønsker å ha psykotiske sinnslidende. Dette er et følsomt område med mange interessemotsetninger. Spørsmålet er om det finnes bedringsmuligheter. Noen mener at det er for få lukkede plasser for pasienter med akutt, subakutt og kronisk sykdom i psykiatrien. En viss kapasitetsøkning vil kunne bedre forholdene på flere måter, men i en tid hvor kapasiteten er begrenset i mange

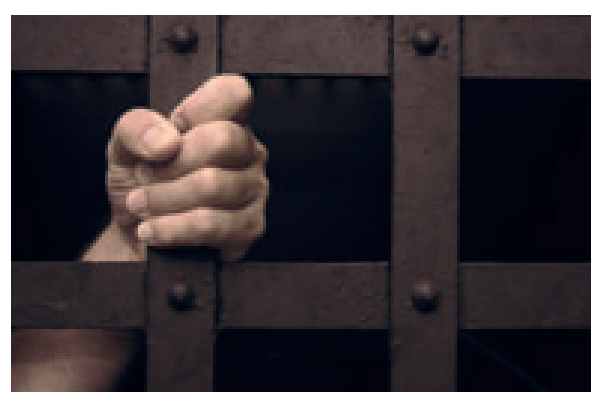

Illustrasjonsfoto Istockphoto

deler av helsevesenet, er det lite sannsynlig at dette vil skje.

En mer realistisk mulighet ligger i Justisdepartementets planer om å opprette ressursavdelinger for innsatte med psykiske lidelser og store atferdsavvik (7). En prioritering av innsatte med psykotiske tilstander vil kunne gi langt mer forsvarlige forhold. Inntil slike avdelinger er opprettet må samfunnet være glad for at det har et fengselsvesen og fengselshelsetjeneste som utøver en viktig jobb. De ansatte her fortjener avlasting, og pasientene trenger et bedre tilbud.

\section{Pål Hartvig}

paal.hartvig@kompetanse-senteret.no

Kompetansesenter for sikkerhets-,

fengsels-og rettspsykiatri

Oslo universitetssykehus

Postboks 4956 Nydalen

0424 Oslo

Oppgitte interessekonflikter: Ingen

\section{Litteratur}

1. Penrose LS. Mental disease and crime: Outline of a comparative study of European statistics. Br J Med Psychol 1939; 18: 1-15.

2. Hartvig P, Kjelsberg E. Penrose's law revisited: The relationship between mental institution beds, prison population and crime rate. Nord J Psychiatry 2009; 63: $51-6$

3. Fazel S, Danesh J. Serious mental disorder in 23.000 prisoners. A systematic review of 62 surveys. Lancet 2002; 359: 545-50.

4. Kjelsberg E, Hartvig P. Can morbidity be inferred from prescription drug use? Results from a nation-wide prison population study. Eur J Epidemiol 2005; 20: 587-92.

5. Torrey EF. Jails and prisons - America's new mental hospitals. Am J Public Health 1995; 85: 1611-3.

6. Kernberg 0 . The almost untreatable narcissistic patient. J Am Psychoanal Assoc 2007; 55: 503-39.

Ressursavdelinger for innsatte med psykiske lidelser og store atferdsavvik. Utredning fra en arbeidsgruppe. Oslo: Justisdepartementet, 2009. 